\title{
The National Flood-Frequency Program-Methods for Estimating Flood Magnitude and Frequency in Rural Areas in Louisiana, 2001
}

\section{Introduction}

Estimates of the magnitude and frequency of flood-peak discharges and flood hydrographs are used for a variety of purposes, such as for the design of bridges, culverts, and flood-control structures; and for the management and regulation of flood plains. To provide simple methods of estimating flood-peak discharges, the U.S. Geological Survey (USGS) has developed and published regression equations for every State, the Commonwealth of Puerto Rico, American Samoa, and a number of metropolitan areas in the United States. In 1993, the USGS, in cooperation with the Federal Emergency Management Agency and the Federal Highway Administration, compiled all current USGS statewide and metropolitan area regression equations into a computer program, titled "The National Flood-Frequency (NFF) Program” (Jennings and others, 1994).

Since 1993, new or updated regression equations have been developed by the USGS for various areas of the Nation. These new equations have been incorporated into an updated version of the NFF Program.

This Fact Sheet describes the application of the updated NFF Program to streams that drain rural areas in Louisiana. Information on obtaining the NFF software and fact sheets for other areas of the Nation is provided at the end of this Fact Sheet.

\section{Overview}

Ensminger (1998) developed regional regression equations for estimating flood discharges $\left(\mathrm{Q}_{\mathrm{T}}\right)$, in cubic feet per second, with recurrence intervals $(\mathrm{T})$ that range from 2 years to 500 years for ungaged, unregulated, rural streams with drainage areas less than or equal to 3,000 square miles. Separate sets of equations were developed for each of two hydrologic regions using standard ordinary-leastsquares procedures. One hydrologic region is composed of the Pine Hills physiographic division in Louisiana (fig. 1). The other hydrologic region is composed of the Alluvial Plains, Prairies, and Coastal Marshes physiographic divisions. A total of 346 streamflow-gaging stations were used in this analysis, 303 in the Pine Hills region and 43 in the non-Pine Hills region. The regional regression equations are included in the NFF Program and explained in this Fact Sheet.
Ensminger (1998) also developed a region-of-influence regression model, which develops a new set of equations to estimate $\mathrm{Q}_{\mathrm{T}}$ for each individual ungaged site. A total of 360 streamflow-gaging stations were included in the region-of-influence regression analysis, which included basins with drainage areas greater than 3,000 square miles. Data from the 50 streamflow-gaging stations with basin and climatic characteristics most similar to those for the ungaged site are used to develop the site-specific regression equations. The stations included in the regression analysis are not necessarily in the same region as the ungaged site.

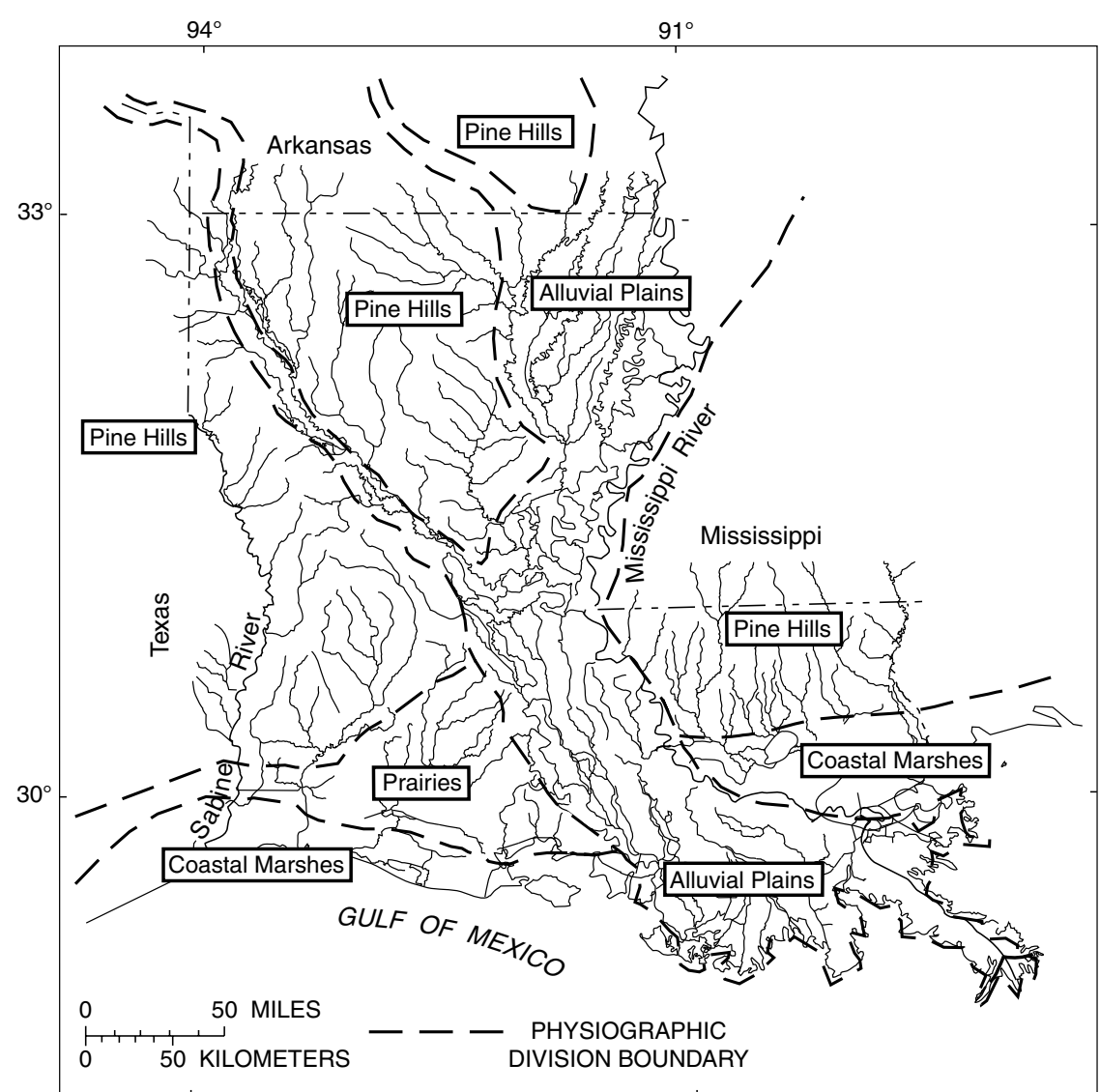

Figure 1. Physiographic divisions of Louisiana 
On the basis of root-mean-square error analysis, Ensminger (1998) concluded that the region-of-influence regression model produced slightly lower errors than the regional regression equations. The reduction in standard error ranged from 1.0 to 3.4 percent. Because the region-of-influence equations and coefficients may change for each ungaged site, it is not possible to include the equations in the NFF Program or in this Fact Sheet. Ensminger (1998) discusses the region-of-influence model in more detail and includes a diskette containing a program for computing region-of-influence estimates.

\section{Procedure}

The regional regression equations developed by Ensminger (1998) are in the inch-pound system of units; however, the NFF Program will accept and report either the inch-pound or the metric system of units. The explanatory watershed and climatic variables used in the equations are as follows:

Drainage area (DA), in square miles, is the contributing drainage area of the basin, and is determined from the best available topographic map.

Channel slope (SLP), in feet per mile, is the main channel slope measured between two points along the main channel, one at 10 percent of the channel length and the other at 85 percent of the channel length, and is determined from the best available topographic map.

Mean annual precipitation (AP), in inches, is the mean annual precipitation for the basin, determined from an equal precipitation map (fig. 2). To improve the overall final regression results, a constant of 35 was subtracted from the mean annual precipitation value. This constant is automatically subtracted from AP in the NFF Program; the user should enter the actual value.

The regional regression equations, the standard error of estimate, and the equivalent years of record are shown in table 1 . The average standard error of estimate is a measure of the goodness of fit between a regression equation and the data

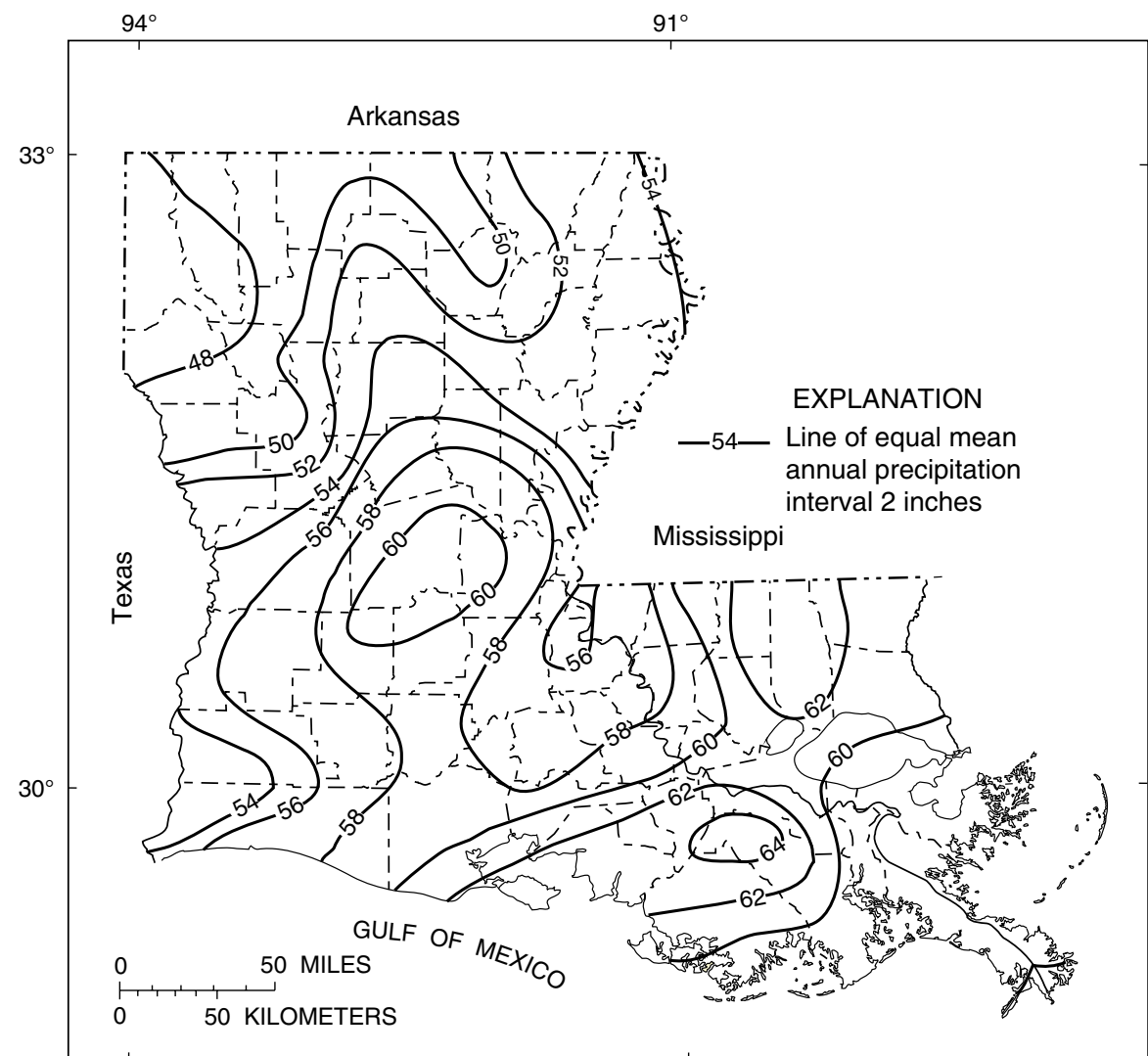

Figure 2. Mean annual precipitation for Louisiana, 1951-1980

Table 1. Regional regression equations and associated statistics for streams that drain rural areas in Louisiana (modified from Ensminger, 1998)

$\left[\mathrm{Q}_{\mathrm{T}}\right.$, peak discharge for recurrence interval T, 2 to 500 years, in cubic feet per second; $\mathrm{A}$, drainage area, in square miles; SLP, main channel slope, in feet per mile; AP, mean annual precipitation, in inches, during the period 1951-1980]

\begin{tabular}{|c|c|c|}
\hline Regression equations & $\begin{array}{c}\text { Standard } \\
\text { error of } \\
\text { estimate, } \\
\text { in percent }\end{array}$ & $\begin{array}{c}\text { Equivalent } \\
\text { years of } \\
\text { record }\end{array}$ \\
\hline \multicolumn{3}{|c|}{ Pine Hills region } \\
\hline$Q_{2}=5.80 D A^{0.744} S L P^{0.374}(A P-35)^{0.796}$ & \pm 47 & 3 \\
\hline$Q_{5}=13.3 D A^{0.760} S L P^{0.385}(A P-35)^{0.694}$ & \pm 42 & 5 \\
\hline$Q_{10}=19.5 D A^{0.768} S L P^{0.392}(A P-35)^{0.658}$ & \pm 41 & 6 \\
\hline$Q_{25}=28.0 D A^{0.778} S L P^{0.401}(A P-35)^{0.629}$ & \pm 43 & 8 \\
\hline$Q_{50}=34.6 D A^{0.785} S L P^{0.407}(A P-35)^{0.616}$ & \pm 46 & 9 \\
\hline$Q_{100}=41.2 D A^{0.791} S L P^{0.412}(A P-35)^{0.610}$ & \pm 49 & 9 \\
\hline$Q_{500}=56.0 D A^{0.803} S L P^{0.425}(A P-35)^{0.608}$ & \pm 57 & 10 \\
\hline \multicolumn{3}{|c|}{ Non-Pine Hills region } \\
\hline$Q_{2}=2.42 D A^{0.683} S L P^{0.297}(A P-35)^{1.21}$ & \pm 42 & 2 \\
\hline$Q_{5}=4.86 D A^{0.716} S L P^{0.432}(A P-35)^{1.02}$ & \pm 39 & 3 \\
\hline$Q_{10}=6.50 D A^{0.736} S L P^{0.506}(A P-35)^{0.935}$ & \pm 41 & 3 \\
\hline$Q_{25}=8.34 D A^{0.759} S L P^{0.588}(A P-35)^{0.859}$ & \pm 45 & 3 \\
\hline$Q_{50}=9.46 D A^{0.776} S L P^{0.642}(A P-35)^{0.817}$ & \pm 49 & 4 \\
\hline$Q_{100}=10.5 D A^{0.792} S L P^{0.691}(A P-35)^{0.783}$ & \pm 53 & 4 \\
\hline$Q_{500}=12.1 D A^{0.826} S L P^{0.794}(A P-35)^{0.726}$ & \pm 64 & 4 \\
\hline
\end{tabular}


Table 2. Range of explanatory variables for which the regional regression equations are applicable for streams that drain rural areas in Louisiana (from Ensminger, 1998)

\begin{tabular}{|c|c|c|}
\hline $\begin{array}{l}\text { Drainage area, } \\
\text { in square miles }\end{array}$ & $\begin{array}{l}\text { Mean channel } \\
\text { slope, in } \\
\text { feet per mile }\end{array}$ & $\begin{array}{l}\text { Mean annual } \\
\text { precipitation, } \\
\text { in inches }\end{array}$ \\
\hline \multicolumn{3}{|c|}{$\underline{\text { Pine Hills region }}$} \\
\hline $0.009-2,947$ & $0.85-247$ & $42-65$ \\
\hline \multicolumn{3}{|c|}{$\underline{\text { Non-Pine Hills region }}$} \\
\hline $0.35-2,287$ & $0.40-20.1$ & $47-67$ \\
\hline
\end{tabular}

used to derive the equation. Errors in the $Q_{T}$ estimates for about two thirds of the stations used in the regression analysis were within the given standard errors. Errors in the $Q_{T}$ estimates for ungaged sites are larger than the standard errors of estimate shown in table 1 . These errors increase appreciably when the drainage area is near or beyond the range limits shown in table 2 . The equivalent years of record is the number of years of streamflow record needed to achieve the same accuracy as the regression equation.

\section{Improving Estimates With Gaged Data}

The U.S. Water Resources Council (1981, appendix 8) described weighting techniques to improve estimates of peak discharge at gaged locations by combining the estimates derived from analysis of gage records with estimates derived from other means, including regression equations. The weights of the two independent estimates are based on the length of the gage record (in years) and the equivalent years of record of the applicable regression equation. The weighted estimate of peak discharge is computed as:

$$
\log Q_{T(G) w}=\frac{N \cdot \log Q_{T(G) s}+E Q \cdot \log Q_{T(G)} r}{N+E Q},
$$

where

$$
\begin{aligned}
Q_{T(G) w} & \begin{array}{l}
\text { is the weighted estimate of dis- } \\
\text { charge } \mathrm{Q} \text { for recurrence interval }
\end{array} \\
& \mathrm{T} \text { at the gage location, } \\
Q_{T(G) s} & \text { is the estimate of } \mathrm{Q}_{\mathrm{T}} \text { derived } \\
& \text { from analysis of the systematic } \\
& \text { gage records, }
\end{aligned}
$$

$Q_{T(G) r}$ is the estimate of $\mathrm{Q}_{\mathrm{T}}$ derived from application of the appropriate regression equation in table 1 ,

$N$ is the number of years in the gage record used to compute $Q_{T(G) s}$, and

$E Q$ is the equivalent years of record (table 1).

The accuracy of the weighted discharge estimate, in equivalent years of record, is equal to $N+E Q$.

This weighting technique is slightly different than a similar technique described by Ensminger (1998). The technique can be used to improve the estimate at the gaged site whether the weighted estimate was determined using the regional regression or the region-of-influence equations. The NFF Program contains an algorithm to perform the weighting computations.

\section{Ungaged Sites Near Gaged Sites on the Same Stream}

Ensminger (1998) showed how the weighted estimate for peak discharge at a gaged site can be used to improve estimates of peak discharge at an ungaged site on the same stream that has a drainage area that is between 50 and 150 percent of the drainage area of the gaged site. The regression estimate for the ungaged site is multiplied by an adjustment factor, which is computed as:

$$
A F=R-\frac{\Delta A(R-1)}{0.5 A_{G}},
$$

where

$A F$ is the adjustment factor,
$\Delta A$ is the absolute value of difference in drainage area between the gaged site $\left(A_{G}\right)$ and the ungaged site $\left(A_{U}\right),\left|A_{G}-A_{U}\right|$, and

$R$ is the ratio of the weighted peakdischarge estimate to the regression estimate for the gaged site, $Q_{T(G) w} / Q_{T(G) r}$

The method can be used to improve the estimate at the ungaged site whether the weighted estimate for the gaged site was determined using the regional regression or the region-of-influence equations. The drainage area at the ungaged site must be within 50-150 percent of the drainage area of the gaged site; otherwise, the estimate at the ungaged site should be based only on the appropriate regression equation.

-Prepared by Robert R. Mason, Jr. and Steven S. Sumioka

\section{References}

Jennings, M.E., Thomas, W.O., Jr., and Riggs, H.C., compilers, 1994, Nationwide summary of U.S. Geological Survey regional regression equations for estimating magnitude and frequency of floods for ungaged sites, 1993: U.S. Geological Survey WaterResources Investigations Report 944002, 196 p.

Ensminger, P.A., 1998, Floods in Louisiana, magnitude and frequency, Fifth Edition: Louisiana Department of Transportation and Development Water Resources Technical Report No. 60, 353 p.

U.S. Water Resources Council, 1981, Guidelines for determining flood flow frequency: U.S. Water Resources Council Bulletin 17B, 28p. 14 appendixes. 


\section{For more information contact:}

U.S. Geological Survey

Office of Surface Water

415 National Center

Reston, Virginia 20192

(703) 648-5301

USGS hydrologic analysis software is available for electronic retrieval through the World Wide Web (WWW) at http://water.usgs.gov/software/ and through anonymous File Transfer Protocol (FTP) from water.usgs.gov (directory: /pub/software).

The WWW page and anonymous FTP directory from which the National FloodFrequency software and user documentation can be retrieved are http://water.usgs.gov/software/nff.html and /pub/software/surface_water/nff, respectively.

Additional earth science information is available from the USGS through the WWW at http://www.usgs.gov/ or by calling 1-888-ASK-USGS. 